\title{
Nutritional Status and its Awareness among School Students in Yadgir District, India
}

\author{
Krutika Chanda*, Mallikarjun Kenganal and Sumangala Nalwar
}

ICAR-Krishi Vigyan Kendra, Yadgir

University of Agriculture Science, Raichur-India

*Corresponding author

\section{Keywords}

Adolescent children, Body

Mass Index,

Nutritional Status,

Nutritional

Awareness and

Nutritional

Education

Article Info

Accepted:

17 May 2019

Available Online:

10 June 2019

\section{A B S T R A C T}

The study was undertaken to assess the Body Mass Index (BMI) of adolescent students to ascertain nutritional status, nutritional awareness level among the student and provide nutritional education to the vulnerable group. The anthropometric measurements like height and weight were recorded to compute the Body Mass Index (BMI) among 125 students studying in $8^{\text {th }}$ and $9^{\text {th }}$ Standard at one of the Government high school of Shorapur taluk, Yadgir district. The BMI was compared with WHO standards based on which inferences were derived. The data was also collected on Socio Economic Status of the students' family and was assessed by using socio- economic scale. A self structured questionnaire was used to assess the knowledge or awareness about the nutritional level among the students. The results indicated that majority were underweight $(55.20 \%)$ followed by per healthy weight $(36.80 \%)$ and few were in overweight category $(8.00 \%)$. The nutritional awareness level of the student was assessed before the intervention program where in majority of the students were unaware of the basic concept of the nutritional food for healthy living. Invariably a significant difference was found between male and female students. While after the intervention, significant increase in the knowledge about the food and nutrition was witnessed. Overall also, significant difference was found between the pre and post test assessment on nutritional awareness level of the students. The study concludes that students in Yadgir district irrespective of caste, community and economic status, they need sound knowledge about the nutritional food for healthy life which determines their career frequently. The adolescents must understand properly about their health and requirements of nutritional food, then only this underprivileged group can prosper in society.

\section{Introduction}

India is home for around 243 million adolescents compared to other country. The term adolescence is derived from the Latin word 'adolescere' meaning "to grow and to mature." The defined given by World Health
Organization (WHO) it's the period of life from 10 to 19 years and characterized by rapid physical growth, significant emotional, psychological and spiritual changes and evolving personal relationships. However, the physical and psychological changes that occur in adolescence can start earlier, during the 
preteen or "tween" years (ages 9 through 12). Adolescents are the best human assets for developing nation. But the health of adolescents has been neglected especially in developing countries because either family can't afford to have a decent nutritious meal or they were considered to be less vulnerable to diseases than the young children or the very old. In recent times, the health of adolescent has attracted the global attention, especially in developing countries which are looking for better tomorrow. The malnutrition among young citizens continues to be a major public health problem throughout the developing world, particularly in sub-Saharan Africa and southern Asia including India. Every year the lives of around 50 million children are put at risk because they are dangerously thin due to acute under nutrition. World is looking towards India for skilled manpower rather just workers. If growing young generation is not sufficiently taken care their future is certainly at risk and nations too. With this background its need of the hour especially in rural communities where concern for young children is very much neglected especially among adolescent girls. Hence, there is a need to educate these adolescent especially about their healthcare.

In the present scenario, nutritional education has become an essential component in improving dietary habits and food choices among the public especially due to increasing health risk attributed to changing food habit and lifestyle. The present study focuses on nutritional status of school children in Yadgir district and is one among the most backward district in the country in many aspects including public health. The district is considered for overall development under the Aspirational Districts programme. Poor dietary habits and lack of physical activity are the main reasons for poor and unhealthy nutritional status among adolescent. While the nutrition knowledge would increase healthy habits at a young age which in turn improves the cognitive development and decrease potential behavioral outbursts. The healthy growing adolescent is the cornerstone of socio-economic development. Their nutritional problems are not just medical problem but multifactorial with roots in many other sectors of developments such as education, demography, agriculture and rural development. The negative impact of being underweight, overweight, or obese on health and development at adolescents can also extend into their adulthood increasing the risk of chronic health issues. With all this background the present study is taken up with an objective to assess the Body Mass Index (BMI) of adolescent students, to assess the nutritional awareness level of student and to provide the nutritional education to the vulnerable group.

\section{Materials and Methods}

Assessment of nutritional health status and its knowledge among the school children was conducted among the school children at Government High School of Shorapur taluka Yadgir district. Total 125 students from $8^{\text {th }}$ and $9^{\text {th }}$ standard were surveyed, interviewed and assessed their Body Mass Index (BMI) to ascertain the recommendations for each of them. Based on the results of nutritional knowledge level, the nutritional education was provided to all the students with pre and post assessment on nutritional level assessment.

Anthropometric measurements like height and weight were taken using measuring rod and digital weighing balance to compute the BMI. The Body Mass Index (BMI) was calculated using the formula,

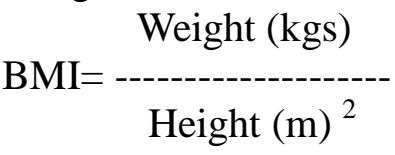


The BMI was compared with the WHO standards. The classification of categories of children is as given in Table 1 .

The data was collected using the Socio Economic Status of the family and assessed by using socio- economic scale developed by Agarwal et al. (2005). The scale consists of 22 statements which assess education, occupation, monthly per capita income from all sources, family possessions, number of children, number of earning members in family, education of children, domestic servants in home, possession of agricultural land and non-agricultural land along with animals and social status of the family. Higher the scores higher is the socio-economic status of the family. The self structured questionnaire was used to assess the nutritional knowledge level among the students. The questionnaire consists of two divisions and each division consisted of 12 questions.

\section{Results and Discussion}

The studies on nutritional health and knowledge are limited to urban dwellers, especially where education, economic status and social living standards are high. The purpose of understanding the poor health among adolescent school children in the most backward district Yadgir were the objectives of the study. It revealed factual reasons and concerns needs to be addressed. The observations documented are tabulated and analysed properly to disseminate the outcome among the study subjects. The table 2 indicates the demographic characteristics of the students while the education and occupation of the parents is considered. With regard to caste, majority of them belonged to Other Backward Communities (OBC) (41.60\%) followed by 28.80 per cent were from upper caste, 19.20 per cent were from SC category and remaining 10.40 per cent belonged to ST category. While in case of education of the parents, about 39.20 per cent had their primary education but $<10^{\text {th }}$ standard followed by 21.60 per cent were just Primary/literate, 20.80 per cent were $10^{\text {th }}$ passed but <graduation, 15.20 per cent were graduates and only 3.20 per cent were illiterates. With regard to occupation of the parents, 41.60 per cent were engaged in farming, petty business and service sectors such as in shops, home or had own cultivation, 39.20 per cent were laborers $<$ Rs 5,000 income or housewives, 12.00 per cent were self employed with income > Rs 5,000 and remaining 7.20 per cent serviced in private sector or independent business. In case of Socio-Economic Status (SES) about 69.80 per cent belonged to lower middle SES followed by 22.40 per cent belonged to poor middle and only 8.80 per cent belonged to upper middle SES.

The gender wise distribution of BMI among the students is tabulated in Table 3 wherein, about 70.76 per cent of the male students were under weight followed by 65 per cent were overweight and only 24.61 per cent had healthy weight. While in case of female student 50.00 per cent belonged to healthy weight, whereas 38.33 per cent belonged to underweight category and 11.66 per cent were overweight. Overall 55.20 per were underweight and only 8.00 per cent were in overweight category. Total 36.80 per cent students had healthy weight. The study by Adesina et al., (2012) was in line with the present study. The results by Silva et al.,(2016) indicated that the comparison of underweight for both sexes was statistically significant. A study by Singh et al., (2014) pointed the similar results 19.5 per cent of the adolescents were stunted with boys and girls equally suffering (50.0\%). The study by Lokeesan et al., (2015) noticed prevalence of underweight is high among grade 5 students due to poor nutrition and no knowledge of 
nutrition diet. Flegal et al., (2014) pointed out that underweight was significantly associated with higher risk of death relative to highnormal weight.

Table.1

\begin{tabular}{|c|l|l|}
\hline SI. No & \multicolumn{1}{|c|}{ Percentile } & \multicolumn{1}{c|}{ Category } \\
\hline $\mathbf{1}$ & Less than $5^{\text {th }}$ percentile & Underweight \\
\hline $\mathbf{2}$ & $5^{\text {th }}$ to $84^{\text {th }}$ percentile & Normal Weight \\
\hline $\mathbf{3}$ & $85^{\text {th }}$ to $94^{\text {th }}$ percentile & Overweight \\
\hline $\mathbf{4}$ & Above $95^{\text {th }}$ percentile & Obese \\
\hline
\end{tabular}

\begin{tabular}{|l|c|}
\hline \multicolumn{1}{|c|}{ Status } & Total Score \\
\hline Upper High & $>76$ \\
\hline High & $61-75$ \\
\hline Upper Middle & $46-60$ \\
\hline Lower Middle & $31-45$ \\
\hline Poor Middle & $16-30$ \\
\hline Very poor & $<15$ \\
\hline
\end{tabular}

Table.2 Demographic characteristics of students

\begin{tabular}{|c|c|c|}
\hline $\begin{array}{l}\text { Sl. } \\
\text { No }\end{array}$ & Particulars & Percentage \\
\hline \multirow[t]{5}{*}{1} & Caste & \\
\hline & Upper Caste & $36(28.80)$ \\
\hline & $\mathrm{OBC}$ & $52(41.60)$ \\
\hline & $\mathrm{SC}$ & $24(19.20)$ \\
\hline & ST & $13(10.40)$ \\
\hline \multirow[t]{6}{*}{2} & Education of parents & \\
\hline & Illiterate & $04(03.20)$ \\
\hline & Primary/literate & $27(21.60)$ \\
\hline & Primary passed but $<10^{\text {th }}$ & $49(39.20)$ \\
\hline & $10^{\text {th }}$ passed but $<$ graduation & $26(20.80)$ \\
\hline & Graduation & $19(15.20)$ \\
\hline \multirow[t]{5}{*}{3} & Occupation of parents & \\
\hline & Service in private sector or independent business & $09(7.20)$ \\
\hline & Service at shops, home, own cultivation & $52(41.60)$ \\
\hline & Self employed with income > Rs 5,000 & $15(12.00)$ \\
\hline & Laborers $<$ Rs 5,000 income, housewives & $49(39.20)$ \\
\hline \multirow[t]{4}{*}{4} & Socio-Economic Status & \\
\hline & Upper Middle & $11(08.80)$ \\
\hline & Lower Middle & $86(68.80)$ \\
\hline & Poor Middle & $28(22.40)$ \\
\hline
\end{tabular}

* Figures in the parenthesis indicates percentage 
Table.3 Gender wise indicator of BMI of students

\begin{tabular}{|l|l|l|l|}
\hline BMI & Male $(\mathbf{N = 6 5})$ & Female $(\mathbf{N = 6 0 )}$ & Total $(\mathbf{N = 1 2 5 )}$ \\
\hline Under Weight & $46(70.76)$ & $23(38.33)$ & $69(55.20)$ \\
\hline Healthy Weight & $16(24.61)$ & $30(50.00)$ & $46(36.80)$ \\
\hline Over Weight & $03(65.00)$ & $07(11.66)$ & $10(8.00)$ \\
\hline
\end{tabular}

Table.4 Assessment of nutritional awareness level among students

\begin{tabular}{|c|c|c|c|c|c|c|}
\hline \multirow[t]{2}{*}{ Particulars } & \multicolumn{2}{|c|}{ Pre-test } & \multirow{2}{*}{ t-test } & \multicolumn{2}{|c|}{ Post-test } & \multirow[t]{2}{*}{ t-test } \\
\hline & Aware & Unaware & & Aware & Unaware & \\
\hline $\begin{array}{l}\text { Iron rich } \\
\text { foods }\end{array}$ & $\begin{array}{c}07 \\
(8.75)\end{array}$ & $\begin{array}{c}73 \\
(91.25)\end{array}$ & \multirow[t]{8}{*}{$1.98 *$} & $\begin{array}{c}71 \\
(88.75)\end{array}$ & $\begin{array}{c}09 \\
(11.25)\end{array}$ & \multirow[t]{8}{*}{$2.05 * *$} \\
\hline $\begin{array}{l}\text { Calcium rich } \\
\text { foods }\end{array}$ & $\begin{array}{c}56 \\
(70.00)\end{array}$ & $\begin{array}{c}24 \\
(30.00)\end{array}$ & & $\begin{array}{c}68 \\
(85.00)\end{array}$ & $\begin{array}{c}12 \\
(15.00)\end{array}$ & \\
\hline $\begin{array}{l}\text { Vitamin C } \\
\text { rich foods }\end{array}$ & $\begin{array}{c}49 \\
(61.25)\end{array}$ & $\begin{array}{c}31 \\
(38.75)\end{array}$ & & $\begin{array}{c}74 \\
(92.50)\end{array}$ & $\begin{array}{c}06 \\
(7.50)\end{array}$ & \\
\hline $\begin{array}{l}\text { Vitamin D } \\
\text { rich foods }\end{array}$ & $\begin{array}{c}39 \\
(48.75)\end{array}$ & $\begin{array}{c}41 \\
(51.25)\end{array}$ & & $\begin{array}{c}62 \\
(77.50)\end{array}$ & $\begin{array}{c}18 \\
(22.50)\end{array}$ & \\
\hline Cereals & $\begin{array}{c}32 \\
(40.00)\end{array}$ & $\begin{array}{c}48 \\
(60.00)\end{array}$ & & $\begin{array}{c}58 \\
(72.50)\end{array}$ & $\begin{array}{c}22 \\
(27.50)\end{array}$ & \\
\hline Pulses & $\begin{array}{c}29 \\
(36.25)\end{array}$ & $\begin{array}{c}51 \\
(63.75)\end{array}$ & & $\begin{array}{c}51 \\
(63.75)\end{array}$ & $\begin{array}{c}29 \\
(36.25)\end{array}$ & \\
\hline Milk product & $\begin{array}{c}80 \\
(100.00)\end{array}$ & $\begin{array}{c}00 \\
(0.00)\end{array}$ & & $\begin{array}{c}80 \\
(100.00)\end{array}$ & $\begin{array}{c}00 \\
(0.00)\end{array}$ & \\
\hline Oil seeds & $\begin{array}{c}74 \\
(92.50)\end{array}$ & $\begin{array}{c}06 \\
(7.50)\end{array}$ & & $\begin{array}{c}78 \\
(97.50)\end{array}$ & $\begin{array}{c}02 \\
(2.50)\end{array}$ & \\
\hline t-test & & & 2 & & & \\
\hline
\end{tabular}

Assessment on awareness or knowledge about the nutrition among students before the intervention of the programme recorded showed diverse opinion and is tabulated in Table 4. The observations show that majority of the students were unaware of the basic concept of nutritional food for healthy living. Among the male and female students significant difference was found during the study. While after the intervention there was a significant increase in the knowledge of the food and nutrition was witnessed. Overall also there was a significant difference found between the pre and post test assessment on nutritional awareness level of the students. A study by Renjini (2014) indicated the similar results with statistically significant increase in nutritional awareness after nutrition education among the test students. Ghaffari et al., (2017) revealed that there was a significant increase in knowledge, attitude, and nutritional behavior of students of experimental students, while there was no any change among students of control group. A study by Elmadbouly (2015) also revealed that there is a statistical significance difference in the nutritional knowledge about food groups. Kantanista and Osinski (2014) concluded that Underweight is associated with lower levels of physical activity in boys. Puri et al., (2007) recorded significant increase in knowledge regarding various nutrients and their sources result of intervention. 
In conclusion, the study highlights the need for nutritional education right from school age as per the results of the study majority of the school children are in underweight category while very few are in healthy category. With regard to nutritional awareness majority of the students were unaware of the food groups and their nutritional importance but after the nutritional education there was significant increase in the nutritional awareness level among the students. Thus this study gives the scope for including the nutritional education as an integral part of a normal school curriculum for elementary age and should entail discussion, education, and activities that promote increased knowledge of nutrition due to which there is a expanded healthy options at home and at school.

\section{References}

Adesina. A., Peterside, O., Anochie, I. and Akani, A,N., 2012, Weight status of adolescents in secondary schools in port Harcourt using Body Mass Index (BMI). Ital. J. Pediatr., 35(31): 1-6.

Agarwal, 2005, A new instrument (scale) for measuring socio-economic status of a family: Preliminary study. Ind. J. Comm. Med., 34 (4): 111-114.

Anonymous, 2007, World Health Organization. Geneva

Elmadbouly, E.A.M., 2015, Impact of nutrition education on knowledge, attitudes among adolescent girls in holy makkah. Int.J.Bio.Pharmacy and Allied Sci., 4(7): 5357-5367.

Flegal,M.K., Kit,K.B. and Graubard, I.B., 2014, Body Mass Index Categories in Observational Studies of Weight and Risk of Death. Am. J. Epidemiol., 180(3): 288-
296.

Ghaffari, M., Hatami, H., Rakhshanderous, S. and Karimi, H., 2017, Effectiveness of Snack- centered Nutrition Education on Promoting Knowledge, Attitude, and Nutritional Behaviors in Elementary Students. Int J Pediatr., 12(5): 6495-6502.

Kantanista, A and Osinski, W., 2014, Underweight in 14 to 16 year-old girls and boys: prevalence and associations with physical activity and sedentary activities. Ann Agric Environ Med., 21(1):114-119

Lokeesan, V., Josepha, J., Kisokanth, G. and Namonithy, S., 2015, Nutritional Status of Grade Five Students in Selected School of Batticaloa District, Sri Lanka. J. Nutr Disorders Ther., 5(3): 2-5.

Puri, S., Bhatia, V., Swami, H. and Mangat, C., 2007, Impact of a diet and nutrition related education package on the awareness and practices of school children of Chandigarh. The Internet. J. Epidemiology. 6(1): 1-7.

Renjini, M.R. 2014, A study on the impact of nutrition education programme conducted for adolescent girls and parents of Changanacherry Taluk of Kottayam district. Int. J. Sci. Res Pub., 4(1):1-3.

Silva, S.C., Junior, S.T.C., Ferreira, S.B., Silva, M.D.F., Silva, S.P. and Xavier, R.A., 2016, Prevalence of underweight, overweight, and obesity among 2,162 Brazilian school adolescents. Ind.J.Endo.Metab., 20(2): 228-232.

Singh, P.J., Kariwal, P., Gupta, B.S., Singh, K.A. and Imtiaz, D., 2014, Assessment of nutritional status among adolescents: a hospital based cross sectional study. Int. J. Res Med Sci., 2(2):620-624

\section{How to cite this article:}

Krutika Chanda, Mallikarjun Kenganal and Sumangala Nalwar. 2019. Nutritional Status and Its Awareness among School Students in Yadgir District. Int.J.Curr.Microbiol.App.Sci. 8(06): 21892194. doi: https://doi.org/10.20546/ijcmas.2019.806.260 